\title{
Pulmonary Artery Leiomyosarcoma
}

National Cancer Institute

\section{Source}

National Cancer Institute. Pulmonary Artery Leiomyosarcoma. NCI Thesaurus. Code C5373.

An aggressive malignant smooth muscle neoplasm, arising from the pulmonary artery It is characterized by a proliferation of neoplastic spindle cells. 